\title{
Audit Services Fee, Non-Audit Services and the Reliability of Earnings
}

\author{
Mazrah Malek and Saidatunur Fauzi Saidin
}

\begin{abstract}
External auditing is essential due to the belief that it can enhance users' reliability of the financial reports. However, negative perception on auditor's independence decreases investors' reliability on the reports. The purpose of this study is to examine the effects of audit and non-audit fees on earnings response coefficient. Negative perception on auditor's independence concerning the high amount of fees decreases the investors' reliability on audited earnings and thus, results in lower ERCs. Based on 270 listed companies on the Bursa Malaysia in 2011, the OLS regression result shows that investors place lower reliability on earnings audited by highly paid auditors. Investors view high fees as a form of compensation to the auditors. The finding is consistent with earlier perceived studies which had found negative perceptions on high fees.
\end{abstract}

Index Terms-Audit fees, non-audit fees, earnings response coefficient, auditor independence.

\section{INTRODUCTION}

Audit failures such as in the case of Enron Corporation, WorldCom Corporation, Global Crossing, ImClone Systems Incorporation and Tyco International have raised concerns on the auditors' ability in discharging their duties. While [1] defined auditor's quality as jointly determined by auditor's competence and independence, the above corporate failures have been related to auditors' failure in exercising their independence.

Remuneration received by an auditor from its client can be in two forms; audit services fee and non-audit services fee. Audit services fee is remuneration for the auditing services, whilst non-audit services fee is remuneration for additional services provided by auditors. Audit services fee has become an issue in auditing due to the possible contradicting effects on audit quality, whereby high audit fees may increase auditor's ability to detect misstatements [2], [3] and on the other hand, may impair auditor's independence [4], [5]. Meanwhile, even though joint-provision could be beneficial in terms of cost saving through knowledge spill-over [6], [7], many believe that it can impair auditor's level of independence [8], [9].

The government's concern has led to the mandatory requirement for the disclosure of both fees and the prohibition of joint provision of audit with certain types of non-audit services. In Malaysia, the disclosure of audit

Manuscript received June 20, 2013; revised August 16, 2013. This work was supported in part by the Universiti Putra Malaysia under Research University Grant Scheme 06-02-12-1970RU.

M. Malek and S. F. Saidin are with the Universiti Putra Malaysia, Selangor, 43400, Malaysia (e-mail: mazrah@econ.upm.edu.my, fauzi@econ.upm.edu.my). services fee in companies' annual reports is required by the Companies Act, 1965. In determining the fees for the audit services, the Malaysian Institute of Accountants (MIA) through its Recommended Practice Guide (RPG) 7 requires auditors to consider the degree of responsibilities, risks and skills involved and the amount of time occupied. It also recommends that the audit services fee be computed on the basis of economic time used. As the benchmark, RPG 7 also requires auditors to consider the value of total assets or turnover in determining the audit services fee. The disclosure of non-audit services fee is only required for listed companies. The MIA through its By-Laws (On Professional Ethics, Conduct and Practice) prohibits auditors from providing valuation services, litigation support services, dispute resolutions and some of the corporate finance services (such as promoting, dealing in or underwriting client's shares). For listed clients, the auditors are also prohibited from providing accounting and bookkeeping services, internal audit services, staff lending and design, provide or implement financial information technology services.

Observation of previous studies have shown an increase trend of audit services fee received by auditors in Malaysia For example, [10] found a 10 percent increase in average audit fees from year 1997 to year 1998. Meanwhile, in year 2003, average audit fees were RM191, 875 [11], whilst in year 2007, the average audit fees was RM248, 376 [12]. Researchers also found that purchasing additional services from auditor is a common practice by Malaysian listed companies. [13] found that 63 percent of the listed companies in year 2002 purchased additional services from its auditor, whilst [14] reported a 44 percent of listed companies in year 2007.

Therefore, the objective of this study is to examine the effects of audit and non-audit fees on earnings response coefficient (ERC). Negative perception on high fees decreases investors' reliability on reported earnings and thus, results in lower ERC.

\section{LITERATURE REVIEW}

\section{A. Financial Reporting and Auditing}

Financial reporting is an important mechanism in the corporate structure which relieves the information asymmetry between management and stakeholders [15]. Minimal involvement in the management limits shareholders' knowledge on corporate activities. Thus, the information provided by financial reports is later useful for shareholders' monitoring purposes and in economic decision-making [16]. 
Accounting data clearly furnishes one type of quantitative data that can be used as a basis for making some of the choices that have to be made from among the alternatives available and for checking and evaluating progress and results [17]. It also provides a common ground for investors to compare firms within or across time periods [18]. Many are skeptical on the quality of financial reporting. It has been criticized to be prepared to conform to the management's needs rather than users' needs, which later can mislead users' judgments [19].

External audit of financial reports is a mandatory requirement for a corporation in most countries. As external to a corporation, an external auditor is believed to be able to enhance the credibility of the financial reports. While the preparation of financial accounts is the management's responsibility, auditors are responsible in determining the correspondence between information provided in the accounts with the standards and give the reports on the correspondence. In fact, [20] argued that financial reports are a joint statement by auditor and management. The intuition is based on the fact that an auditor may request for adjustments in the financial reports if they are not satisfied with the accounts prepared by the management. If the adjustments have not been properly made, auditors can highlight the incompliance in their reports.

However, audit failures involving multinational corporations have raised concerns on the auditors' ability in discharging their duties. While [1] defined auditor's quality as jointly determined by auditor's competence and independence, the corporate failures have been related to auditors' failure in exercising their independence.

\section{B. Auditor Independence}

Independent auditing has been recognized as an essential feature of efficient capital markets and regulators have long been concerned with the potential threats to auditor independence [8]. The independent status of an auditor gives value and significance to audit reports [21]. Independence is not easily defined, but many agree the importance of both independence of mind and independence in appearance [22]. Therefore, auditors are not only required to be independent but also be seen as independent.

Two approaches have been used by researchers in examining the factors that may affect auditor independence which are survey and theory-driven. Survey approach requires researchers to conduct surveys on auditors and financial statement users regarding their perception on an auditor's independence [4], [5], [23], [24]. However, there has been evidence on the existence of expectation gaps between the subjects. Due to this, increasing studies have been done by using the theory driven approach, which permits a more objective investigation. This approach which is done by using archival data to measure behavioral constructs necessitates the use of proxies to measure the underlying behavioral relationships [25].

\section{Audit Fees}

Earlier studies on audit fees were to examine the determinants of audit fees which has been driven by the concerns of anti-competitive pricing that may be practiced by large accounting firms [26]. However, no evidence exists to conclude the occurrence of the practice and in fact, findings have indicated that audit services fee is influenced by the audit work undertaken by auditors [12], [27]. Based on the findings, later studies have postulated that high audit fees relates to high audit quality [28]-[30]. However, the postulation of high quality audit by highly paid auditors can be questioned, whereby high audit fees may impair auditor's independence [31], [32]. It is argued that an auditor is relatively more dependent on a client when a significant portion of the auditors' fee comes from that client and this dependency may reduce the auditor's ability to resist pressure from the client [4], [5]. When a particular client is considered important to an auditor (in this case financially), the client may have the power to persuade the auditor [5]. The government's response towards the concerns has led to the mandatory requirement for audit services fee disclosure by some countries. For example, SEC registrants companies are required to disclose the audit services fee beginning from February 5, 2001. Even though, the requirements do not assure that auditor's independence is not being compromised, the disclosure at least would provide some basic information to the users on the possible impairment of auditor's independence.

\section{Non-Audit Fees}

Besides audit services, accounting firms also provide some other services. [33] argued that the additional services provided by an audit firm are motivated from the incentives to gain competitive advantage, lesser profit from audit services alone, personnel attraction and retention, accommodating the needs of clients and risk diversification. The non-audit services are becoming an issue in auditing due to the joint provision of audit with non-audit services. Even though joint-provision could be beneficial in terms of cost saving through knowledge spillovers [6], [7], the possible effects on the impairment of auditor's independence have become a concern [8], [9]. Providing non-audit services can be interpreted as a creation of a new basis of self-interest conflict [34]. The government's concern has led to the prohibition of joint provision of audit with certain types of non-audit services and the mandatory requirement for the disclosure in some countries. For example, in Australia the disclosure for non-audit services is required by the Companies Act 1982 and listed companies in the U.S. have been required for the disclosure by the Securities Commissioner (SEC) since 2001. [35] highlights two possible influence of providing non-audit services to audit clients on auditor's independence; as fee dependency and conflict of interest. He argued that auditors are more dependent to an audit client when the same auditor provides both services to the audit client. Thus, an auditor might give-in to auditees' pressure due to the concern of losing the lucrative non-audit services [34]. In addition, [35] also argued that the self-interest conflict when auditing the non-audit services work may cause the auditor to be reluctant to adversely report on non-audit services items.

\section{THEORETICAL FRAMEWORK}

Reference [36] models the investors' reactions on the reported earnings as the function of the prior uncertainty 
about the underlying value of the entity and the perceived noise in the entity's reported numbers. The study postulated that by holding the prior uncertainty about cash flows constant, the ERC will increase with the perceived quality of the earnings' signal. Reported earnings which are viewed to have higher reliability by the investors, will have higher response. Based on [36]'s model, several studies have provided empirical evidence that earnings with less noise is associated with higher earnings response coefficient. [37] found higher earnings response coefficients for audited semi-annual interims rather than unaudited semi-annual interims. In an auditor change study, [38] found lower earnings response coefficient for companies that switched auditors for disagreement-related or fee-related reasons but higher earnings response coefficient for companies that switched auditors for services-related reasons.

The relationship between audit and non-audit fees with ERC lies on the perceived auditor's independence. Negative view on auditor independence from high fees decreases investors' reliability on earnings. Therefore, companies which pay higher audit and non-audit fees are expected to have lower ERC.

A study by [31] which had found that audit fees is significant and positively related to accruals and a study by [35] which had found negative relationship beween audit fees and qualified audit opinion provides evidence of the possible impairment of auditor's independence when an auditor receives high audit fees from an audit client. Meanwhile, [23] and [4] had found that the size of audit fees is the most significant perceived factor affecting impairment of auditor independence among loan officers and is supported by [24] using public and non-public accountants as respondents. Meanwhile, eventhough general beliefs view that non-audit services impair auditor's independence, past studies have shown weak evidence to conclude the beliefs. Even though [39] and [40] had found that loan officers and financial analysts perceived negative effect of outsourcing internal audit to external auditor on auditor independence, [5] found that purchasing non-audit services was not related to client's perceptions about their ability to persuade auditors.

\section{Methodology}

\section{A. Sample and Procedures}

Analysis is based on listed companies in the Bursa Malaysia for the year 2011 which comprises of 956 companies as at 31 December 2011. For the purpose of sampling, all companies were sorted alphabetically and selected based upon the first company for every 3 companies which brings to a total sample of 318 companies. However, due to unavailable annual reports (30 companies) and the unavailability of share price data (18 companies), only 270 companies are used as the final sample.

\section{B. Research Model and Measurements}

The effects of audit and non-audit fees on ERC are examined using the OLS regression and takes the following form:

$\mathrm{CAR}=\beta 0+\beta 1 \mathrm{EP}+\beta 2 \mathrm{EP} \times \mathrm{FEE}+\beta 3 \mathrm{EP} \times \mathrm{TENURE}+$ $\beta 4 \mathrm{EP} \times \mathrm{OPINION}+\beta 5 \mathrm{ASSET}+\mu$
CAR is measured by cumulative abnormal returns for 3 days (on announcement date and 2-day after). The Sharpe (1964)'s market model is used in measuring the abnormal returns. The abnormal return (ARit) of stock $i$ on date $t$ will be calculated as the difference between the actual return (Rit) and the expected return [E(Rit)] for this date as follows:

$$
\text { ARit=Rit }-\mathrm{E}(\mathrm{R} i t)
$$

The actual return Rit of stock $i$ on date $t$ is calculated as the difference between the closing price on date $t$ (Pit) and date $t-1$ (Pit-1) divided by closing price on the date $t-1$ (Pit-1) as follows:

$$
\text { Rit }=(\text { Pit }- \text { Pit-1) } /(\text { Pit-1) }
$$

The expected returns E(Rit) is calculated as follows:

$$
\mathrm{E}(\mathrm{Rit})=\alpha i+\beta i \mathrm{Rmt}
$$

The model assumes a stable linear relation between the market return and the share return. The estimated coefficients, $\alpha$ and $\beta$ are calculated by regressing the stock returns with market returns using daily closing prices and daily Bursa Malaysia Composite Index over the 200 trading days $(-230 ;-31)$ using the OLS regression. The FTSE Bursa Malaysia Composite Index will be used as a proxy for the market return (Rmit). It is calculated as the difference between the market index on date $t$ and date $t-1$ divided by the market index on the date $t-1$ as follows:

$$
\text { Rmit }=(\mathrm{I} i t-\mathrm{I} i t-1) /(\mathrm{I} i t-1)
$$

EP is measured by dividing the difference between the actual earnings per share and expected earnings per share with the market value of shares 2 days prior to the announcement date. However, whilst earnings forecast (the measurement usually used for expected earnings) is not publicly available in Malaysia, consistent with prior Malaysian studies, the naive expectation model is used [41], [42]. The model assumes that the next period's expected earnings is the current period's earnings. Therefore, the following measurement will be used in measuring earnings performance:

$$
\mathrm{EP} i t=(\mathrm{EPSit}-\mathrm{EPS} t-1) /(\mathrm{P} i-2)
$$

FEE is measured by the natural logarithm of total audit and non-audit fees. As hypothesized, the interaction between FEE and EP is expected to have a significant negative relationship with CAR.

TENURE is measured by the natural logarithm of number of years the auditor provided audit services to the observed company. As evident by [43], the interaction between TENURE and EP is expected to have a positive relationship with CAR.

OPINION is a dichotomous variable, where the value of 1 if the observed company received a standard unqualified audit opinion and the value of 0 if the observed company received other types of audit opinion is used as the measurement. Companies receiving unqualified audit 
opinion are expected to have higher earnings response coefficient as compared to companies receiving other types of audit opinion. Therefore, the interaction between OPINION and EP is expected to have a positive relationship with CAR.

ASSET is measured by the natural logarithm of total assets. It is expected to have a positive relationship with CAR.

\section{RESULTS}

\section{A. Descriptive Statistics}

Table I presents the result of the descriptive statistics for continuous data. Cumulative Abnormal Return (CAR) ranges between -0.5 to 0.3 , with an average of -0.003 and a standard deviation of 0.06 . The average EP is -0.2 with a standard deviation of 15. On average, an auditor receives a total fee of RM411,000 from a client with the maximum of almost RM11,000,000. Audit fees range between RM15,000 to RM4,267,000 The average audit fees of RM301,000 is higher from the ones reported by [2012] for the year 2007. On average, the non-audit services fee of all sample companies is RM110,000 with the maximum of RM6,760,000. Even though, the average non-audit fees is slightly higher than the ones reported in year 2007 by [14], it is however, much lower than the year 2002 [13]. The average audit tenure is almost 8 years with a maximum of 13 years. Asset size ranges between RM3 million and RM156 billion with an average of RM2.3 billion.

TABLE I: DESCRIPTIVE STATISTICS OF CONTINUOUS DATA

\begin{tabular}{lrrrr}
\hline \hline Variable & Minimum & \multicolumn{1}{c}{ Maximum } & \multicolumn{1}{l}{ Mean } & \multicolumn{1}{c}{ Std. Dev. } \\
\hline CAR & -.507 & .266 & -.003 & .060 \\
EP & -49.455 & 47.667 & -.237 & 14.503 \\
TFEE & 15,000 & $10,978,003$ & 411,143 & $1,013,888$ \\
AFEE & 15,000 & $4,267,000$ & 301,076 & 573,534 \\
NAFEE & 0 & $6,760,003$ & 110,068 & 510,936 \\
ATENURE & 1 & 13 & 7.637 & 4.247 \\
ASSET & 3,028 & $15,620,000$ & $2,300,000$ & $12,100,000$ \\
\hline \hline
\end{tabular}

CAR = cumulative abnormal return; EP = earnings performance; TFEE = total audit and non-audit fees in Ringgit Malaysia; AFEE = audit fees in Ringgit Malaysia; NAFEE = non-audit fees in Ringgit Malaysia; ATENURE $=$ audit tenure in years; ASSET $=$ asset size in RM'000.

Table II presents the result of the descriptive statistics for dichotomous data. Most of the sample companies (94 percent) received unqualified audit opinion, whilst only a few companies (6 percent) received other types of audit opinion. Meanwhile, 75 percent of sample companies purchased additional services from their auditors.

\begin{tabular}{lrr} 
TABLE II: DESCRIPTIVE STATISTICS OF DICHOTOMOUS DATA \\
\hline \hline Variable & Number & \multicolumn{2}{c}{ Percentage } \\
\hline OPINION & 254 & 94 \\
Unqualified & 16 & 6 \\
Others & & \\
NAS & 202 & 75 \\
Purchaser & 68 & 25 \\
$\quad$ Non-purchaser & \\
\hline \hline
\end{tabular}

Table III presents the result of the descriptive and univariate analyses of audit and non-audit fees based on purchaser and non-purchaser of non-audit services companies. On average, purchaser companies paid RM147,000 for non-audit services with a standard deviation of RM586,000. The table also shows that purchaser companies paid higher audit fees than non-purchaser companies. The average audit fees of purchaser companies is RM339,000, ranging from RM18,000 to RM4,267,000. Meanwhile, the average audit fees of non-purchaser companies is only RM189,000, ranging from RM15,000 to $\mathrm{RM} 2,430,000$. T-test shows that the mean difference is significant which suggests that purchaser companies pay much higher audit fees than non-purchaser companies.

TABLE III: DESCRIPTIVE AND UNIVARIATE STATISTICS

\begin{tabular}{|c|c|c|c|}
\hline Variable & Non-Purchaser & Purchaser & t-test \\
\hline \multicolumn{4}{|l|}{ Non-Audit Fees } \\
\hline Minimum & & 650 & \\
\hline Maximum & & $6,760,000$ & \\
\hline Mean & & 147,120 & \\
\hline Standard deviation & & 586,426 & \\
\hline \multicolumn{4}{|l|}{ Audit Fees } \\
\hline Minimum & 15,000 & 18,000 & \\
\hline Maximum & $2,430,000$ & $4,267,000$ & \\
\hline Mean & 189,211 & 338,733 & \multirow{2}{*}{$-1.868^{* *}$} \\
\hline Standard deviation & 342,011 & 628,948 & \\
\hline
\end{tabular}

\section{B. Pearson Correlation Matrix}

Table IV presents the result of the Pearson correlation matrix between CAR, EP, FEE, TENURE, OPINION and ASSET. Except for FEE and OPINION, other variables are significantly correlated with CAR. The high correlation between FEE and ASSET (and is significant) is consistent with audit fees' studies where asset size is found as among the main factors affecting audit fees [12]-[27]. The correlations among other variables are considerably low.

TABLE IV: PEARSON CORRELATION MATRIX

\begin{tabular}{lrrrrr}
\hline \hline Variable & CAR & EP & FEE & TENURE & OPINION \\
\hline EP & .142 & & & & \\
FEE & $(.020)$ & & & & \\
& .091 & .012 & & & \\
TENURE & $.135)$ & $(.840)$ & & & \\
& .124 & .111 & .159 & & \\
OPINION & $(.041)$ & $(.068)$ & $(.008)$ & & \\
& $(.0 .026$ & -0.021 & -0.038 & -.039 & \\
ASSET & .114 & .023 & .770 & .223 & .007 \\
& $(.062)$ & $(.702)$ & $(.000)$ & $(0.00)$ & $(.909)$ \\
\hline
\end{tabular}

CAR = cumulative abnormal return; $\mathrm{EP}=$ earnings performance; $\mathrm{FEE}=$ tota audit and non-audit fee; TENURE = audit tenure; OPINION $=1$, standard unqualified opinion 0, other types audit opinion; ASSET $=$ asset size.

\section{OLS Regression Result}

Table $\mathrm{V}$ presents the result of the OLS regression. The model is significant at a 1 percent level with an adjusted $\mathrm{R}$-squared of 0.039 . Low adjusted $\mathrm{R}$-square is consistent with earlier studies [38], [43], [44]. As expected, the coefficient of variable EP is significant and positive which proves that earnings performance is positively related to abnormal returns.

The coefficient of EP*FEE is negative and significant at 5 percent significant level. The result suggests that audit fee is 
negatively related to ERC. This implies that investors perceive lower reliability on company's earnings audited by highly paid auditors. High fee paid to auditors is viewed as impairing the auditor's independence in discharging their responsibilities. Result is consistent with earlier findings by [4] and [23] and [24] whom also found negative perceptions on high fees.

As expected, the coefficient of EP*TENURE is positive and significant. It implies that investors' reliability on earnings increase with the audit tenure. The result is consistent with an earlier study by [43]. ASSET is also found positive and significantly related to CAR. However, the coefficient of EP*OPINION is found insignificant.

TABLE V: OLS REGRESSION RESULT

\begin{tabular}{lcrrc}
\hline \hline Variable & Exp. sign & Coefficient & $\mathrm{t}$ & $\mathrm{p}$-value \\
\hline EP & + & .008 & 1.71 & $.044 * *$ \\
EP*FEE & - & -.001 & -1.61 & $.050 * *$ \\
EP*TENURE & + & .001 & 1.87 & $.031 * *$ \\
EP*OPINION & + & -.001 & -1.13 & .131 \\
ASSET & + & .010 & 2.05 & $.021 * *$ \\
Constant & & -.093 & -2.14 & $.017 * *$ \\
Adjusted R-square & & .039 & & $.009 *$ \\
\hline * significant at 1 percent, $* *$ significant at 5 percent level, *** significant at
\end{tabular}

* significant at 1 percent, ${ }^{*} *$ significant at 5 percent level, $* * *$ significant at 10 percent level.

Dependent variable, $\mathrm{CAR}=$ cumulative abnormal return; $\mathrm{EP}=$ earnings performance; FEE = audit and non-audit fee; TENURE = audit tenure; OPINION $=1$, standard unqualified opinion 0 , other types audit opinion; ASSET $=$ asset size.

Table VI presents the result of the OLS regression by separating audit and non-audit fees. In this regression, the variable representing audit fees (AFEE) is measured by the natural logarithm of audit fees, whilst the variable representing non-audit fees (NAFEE) is measured by the natural logarithm of non-audit fees. The model is significant at 10 percent, with an adjusted R-squared of 0.035 . Consistent with the earlier regression, the coefficients of EP, ASSET and EP*TENURE are positive and significantly related to CAR. However, the coefficient of EP*NAFEE is insignificant, whilst the coefficient of EP*AFEE is negative and marginally significant. Considering earlier regression analysis, the result suggests that investors look on the total fees received by auditors and not individual fees categorization (i.e. audit fees or non-audit fees).

TABLE VI: OLS REGRESSION RESULT

\begin{tabular}{lcrrc}
\hline \hline & & & & \\
Variable & Exp sign & Coefficient & $\mathrm{t}$ & $\mathrm{p}$-value \\
\hline EP & + & .008 & 1.68 & $.047^{* *}$ \\
EP*AFEE & - & -.001 & -1.59 & $.056^{* * *}$ \\
EP*NAFEE & - & .000 & .53 & .299 \\
EP*TENURE & + & .001 & 1.82 & $.035^{* *}$ \\
EP*OPINION & + & -.001 & -.94 & .174 \\
ASSET & + & .010 & 1.94 & $.027^{* *}$ \\
Constant & & -.088 & -2.01 & $.023^{* *}$ \\
Adjusted R-square & & .035 & & $.056^{* * *}$ \\
\hline \hline
\end{tabular}

* significant at 1 percent, $* *$ significant at 5 percent level, $* * *$ significant 10 percent level.

Dependent variable, $\mathrm{CAR}=$ cumulative abnormal return; $\mathrm{EP}=$ earnings performance; $\mathrm{AFEE}=$ audit fees; $\mathrm{NAFEE}=$ non-audit fees; TENURE $=$ audit tenure; OPINION = 1 , standard unqualified opinion 0 , other types audit opinion; ASSET = asset size.

\section{CONCLUSION}

This study provides empirical evidence of the influence of audit and non-audit fees on investors' reliability on audited earnings based on Malaysian data where audit and non-audit fees disclosure are mandatory. Analyses show that high fees results in lower earnings response coefficient. Findings suggest that investors place lower reliability on financial reports audited by auditors whom receive high remuneration from their auditee. This may possibly be due to the investors' view that high fee is a form of compensation to auditors for compromising their independence. It is also found that investors look on the total fees and not individual audit or non-audit fees received by auditors.

\section{REFERENCES}

[1] L. E. DeAngelo, "Auditor size and audit quality," Journal of Accounting \& Economics, vol. 3, no. 3, pp. 183-199, 1981.

[2] K. A. Houghton and C. A. Jubb, "The costs of audit qualification: The roles of non-audit services," Journal of International Accounting, Auditing \& Taxation, vol. 8, no. 2, pp. 215-240, 1999

[3] M. J. Peel and M. A. Clatworthy, "The relationship between corporate governance structure and audit services fees pre-Cadbury: Some empirical findings," Corporate Governance: An International Review, vol. 9, no. 4, pp. 286-297, 2001.

[4] F. Gul, "Size of audit services fees and perceptions of auditors' ability to resist management pressure in audit conflict situations," ABACUS, vol. 27, no. 2, pp. 162-172, 1991.

[5] V. M. Iyer and D. V. Rama, "Clients' expectations on audit judgements: A note," Behavioral Research in Accounting, vol. 17, pp. 63-74, 2004.

[6] L. Barkess and R. Simnett, "The provision of other services by auditors: Independence and pricing issues," Accounting and Business Research, vol. 24, no. 94, pp. 99-108, 1994.

[7] D. Simunic, "Auditing, consulting and auditor independence," Journal of Accounting Research, vol. 22, no. 2, pp. 679-702, 1984.

[8] M. DeFond, K. Raghunandan, and K. Subramanyam, "Do non-audit service fees impair auditor independence? Evidence from going-concern audit opinions," Journal of Accounting Research, vol. 40, no. 4, pp. 1247-1274, 2002.

[9] D. Hay, R. Knechel, and V. Li, "Non-audit services and auditor independence: New Zealand evidence," Journal of Business Finance \& Accounting, vol. 33, no. 5-6, pp. 715-734, 2006.

[10] H. Hariri, N. Abdul Rahman, and A. Che Ahmad, "An empirical evidence of audit firm merger and audit pricing in Malaysia," Journal of Financial Reporting and Accounting, vol. 5, no. 1, pp. 1-19, 2007.

[11] P. Yatim, P. Kent, and P. Clarkson, "Governance structures, ethnicity and audit services fees of malaysian listed firms" Managerial Auditing Journal, vol. 21, no. 7, pp. 757-782, 2006.

[12] M. Malek and A. Che Ahmad, "Director-auditor link and audit quality," in Corporate Governance Practices in Malaysia, Z. Muhamad Sori, R. Mohd. Said, M. Malek, and R. Senik, Ed. Selangor: Universiti Malaysia Press, 2012, ch. 9, pp. 139-157.

[13] A. Che Ahmad, K. Houghton, and N. Z. Mohamad Yusof, "The Malaysian market for audit services: Ethnicity, multinational companies and auditor choice," Managerial Auditing Journal, vol. 21, no. 7, pp. 702-723, 2006

[14] M. Malek and A. Che Ahmad, "The effect of director-auditor link on non-audit services fee," in Corporate Governance Practices in Malaysia, Z. Muhamad Sori, R. Mohd. Said, M. Malek, and R. Senik, Ed. Selangor: Universiti Malaysia Press, 2012, ch. 10, pp. 158-176.

[15] G. Whittington, "Corporate governance and the regulation of financial reporting," Accounting and Business Research, vol. 23, no. 91A, pp. 311-319, 1993.

[16] B. Lev and J. A. Ohlson, "Market-based empirical research in accounting: A review, interpretation, and extension," Journal of Accounting Research, vol. 20, pp. 249-322, 1982.

[17] D. E. Stone, "The objective of financial reporting in the annual report," Accounting Revie, vol. 42, no. 2, pp. 331-337, 1967.

[18] F. D. Hodge, "Hyperlinking unaudited information to audited financial statements: Effects on investor judgments," The Accounting Review, vol. 76, no. 4, pp. 675-691, 2007

[19] D. N. Ibrahim, K. Raman, and S. F. Saidin, "Audit committee characteristics and quality of unaudited financial accounts," Singapore Management Review, vol. 31, no. 2, pp. 19-33, 2009. 
[20] R. Antle and B. Nalebuff, "Conservatism and auditor-client negotiations," Journal of Accounting Research, vol. 29, no. 3, pp. 31-54, 1991.

[21] D. Lavin, "Perceptions of the independence of the auditor," The Accounting Review, vol. 51, no. 1, pp. 41-40, January 1976.

[22] J. Houghton and C. Jubb, "The market for financial report audits: Regulation of and competition for auditor independence," Law \& Policy, vol. 25, no. 3, pp. 299-321, 2003.

[23] V. Beattie and S. Fearnley, "Perceptions of auditor independence: U.K evidence," Journal of International Accounting, Auditing and Taxation, vol. 8, no. 1, pp. 67-107, 1999.

[24] S. H. Teoh and C. C. Lim, "An empirical study of the effects of audit committees, disclosures of non-audit services fees, and other issues on audit independence: Malaysian evidence," Journal of International Accounting, Auditing and Taxation, vol. 5, no. 2, pp. 231-248, 1996.

[25] M. A. Seabright, D. A. Levinthal, and M. Fichman, "Role of individual attachments in the dissolution of interorganizational relationships," Academy of Management Journal, vol. 35, no. 1, pp. 122-160, 1992.

[26] A. Che Ahmad, "The Malaysian market for audit services: A test of ethnic and regional quality issues," Ph.D. dissertation, The University of Melbourne, Melbourne, Australia, 2001.

[27] L. Ji-hong, "On dterminants of audit services fee: New evidence from China," Journal of Modern Accounting \& Auditing, vol. 3, no. 4, pp. 60-64, 2007.

[28] E. A. Abdul Wahab, E. A. Mat Zain, K. James, and H. Haron, "Institutional investors, political connection an audit quality in Malaysia," Accounting Research Journal, vol. 22, no. 2, pp. 167-195, 2009.

[29] J. V. Carcello, D. Hermanson, T. Neal, and J. R. Riley, "Board characteristics, audit committee characteristics and audit services fees," Contemporary Accounting Research, vol. 19, no. 3, pp. 365-384, 2002.

[30] Z. Salleh, J. Stewart, and S. Manson, "The impact of board composition and ethnicity on audit quality: Evidence from Malaysian companies," Malaysian Accounting Review, vol. 5, no. 2, pp. 61-83, 2006.

[31] R. Antle, E. Gordon, G. Narayanamoorthy, and L. Zhou, "The joint determination of audit services fees, non-audit services fees, and abnormal accruals," Review of Quarterly Financial Account, vol. 27, no. 3, pp. 235-266, 2006.

[32] M. A. Geiger and D. V. Rama, "Audit services fees, nonaudit services fees, and auditor reporting on stressed companies," Auditing: A Journal of Practice \& Theory, vol. 22, no. 2, pp. 53-69, 2003.

[33] S. H. Chien and Y. S. Chen, "The provision of non-audit services by accounting firms after the Enron bankruptcy in the United States," International Journal of Management, vol. 22, no. 2, pp. 300-306, 2005.

[34] A. Goldman and B. Barlev, "The auditor-firm conflict of interest: Its implication for independence," Accounting Review, vol. 49, no. 4, pp. 707-718, 1974
[35] M. Firth, "Auditor-provided consultancy services and their associations with audit services fees and audit opinions," Journal of Business Finance \& Accounting, vol. 29, no. 5\&6, pp. 661-693, 2002.

[36] R. Holthausen and R. Verrecchia, "The effect of sequential information releases on the variance of price changes in an intertemporal multi-asset market," Journal of Accounting Research, vol. 26, no. 1, pp. 82-106, 1988.

[37] I. Haw, D. Qi, and W. Wu, "The economic consequence of voluntary auditing," Journal of Accounting, Auditing \& Finance, vol. 23, no. 1, pp. 63-93, 2008.

[38] K. E. Hackenbrack and C. E. Hogan, "Market response to earnings surprises conditional on reasons for an auditor change," Contemporary Accounting Research, vol. 19, no. 2, pp. 195-223, 2002.

[39] D. Lowe, M. Geiger, and K. Pany, "The effects of internal audit outsourcing on perceived external auditor independence," Auditing; A Journal of Practice \& Theory, vol. 18, no. 2, pp. 7-26, 1999.

[40] S. Swanger and J. Chewning, "The effect of internal audit outsourcing on financial analysts' perceptions of external auditor independence," Auditing: A Journal of Practice \& Theory, vol. 20, no. 2, pp. 115-129, 2001.

[41] C. F. Fah and A. Nasir, "Are islamic incomes relevance to commercial banks in Malaysia?" Journal of Modern Accounting and Auditing, vol. 6, no. 2, pp. 26-37, 2010.

[42] B. M. Hussin, A. D. Ahmed, and T. C. Ying, "Semi-strong form efficiency: Market reaction to dividend and earnings announcements in Malaysian stock exchange," IUP Journal of Applied Finance, vol. 16, no. 5, pp. 36-60, 2010.

[43] A. Ghosh and D. Moon, "Auditor tenure and perceptions of audit quality," Accounting Review, vol. 80, no. 2, pp. 585-612, 2005.

[44] S. W. Teoh and T. J. Wong, "Perceived auditor quality and the earnings response coefficient," Accounting Review, vol. 68, no. 2, pp. 346-366, 1993.

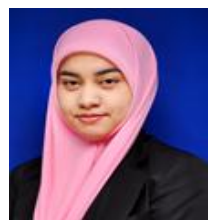

Mazrah Malek is currently a senior lecturer in the Department of Accounting and Finance, Faculty of Economics and Management, Universiti Putra Malaysia. She obtained her Ph.D. from the Universiti Utara Malaysia. Her research interests are in the fields of auditing and corporate governance.

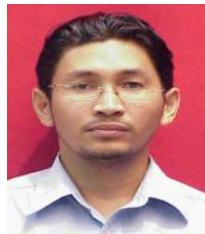

Saidatunur Fauzi Saidin is currently a tutor in the Department of Accounting and Finance, Faculty of Economics and Management, Universiti Putra Malaysia. He obtained his M.A from the Universiti Sains Malaysia. His research interests are in the fields of auditing, corporate governance and financial reporting. 